\title{
Kazık Nihai Taşıma Gücünün Farklı Yöntemlerle Analizi
} Analysis of Pile Ultimate Bearing Capacity by Different Methods

\author{
Halil Kabaca ${ }^{1}$, İsa Vural ${ }^{2}$, Semiha Poyraz ${ }^{3 *}$ \\ Geliş / Received: 08/01/2021 \\ Revize / Revised: 04/08/2021 \\ Kabul / Accepted: 05/08/2021
}

\section{ÖZ}

Kentleşmenin günümüzde hızla artması ve buna paralel olarak dar alanlarda yüksek ve ağır yapıların inşa edilmesinde zemin koşullarının dikkate alınma ihtiyacı daha da önem kazanmaktadır. Zayıf zemin koşullarında kazık temel seçimi taşıma gücü değerlerine olumlu katkı sağlayabilmektedir. Kazık taşıma gücü belirlenmesinde yapılan hatalar güvensiz sonuçlara veya ekonomiklikten uzaklaşmaya sebep olabilmektedir. Bu nedenle kazık taşıma gücü değerinin hesaplanmasında gerçeğe yakın değer elde etmek yapı güvenliği ve ekonomiklik açısından önemlidir. Çalışma kapsamında 8 adet kazık yükleme deneyi doğrudan Standart Penetrasyon Deneyi (SPT) verilerine dayalı yöntemler, dolaylı SPT verilerine dayalı yöntemler, matematiksel modele dayalı kazık yükleme deneyi değerlendirme yöntemleri ve sonlu elemanlar yöntemi ile taşıma gücü değerleri elde edilmiş ve yöntemler karşılaştırılmıştır. Kazıkların farklı zemin koşullarında bulunması haline göre taşıma gücünün belirlenmesi ile ilgili birbiriyle ve ortalama ile en uyumlu yöntemler tespit edilmiştir. Tüm deney sonuçları göz önüne alındığında ortalama taşıma gücü değerine en yakın sonuçlar Bazaara \& Kurkur, Plaxis 2D ve Decourt (1995) yöntemleri ile elde edilmiştir.

Anahtar Kelimeler-Kazık Yükleme Deneyi, Nihai Taşıma Gücü, Fore Kazık, Analiz Yöntemleri

\begin{abstract}
With the rapid increase in urbanization and parallel to this, the need to take into account the soil conditions in the construction of high and heavy structures in narrow areas becomes more important. In poor soil conditions, the choice of pile foundation can make a positive contribution to the bearing capacity values. Errors in determining the pile bearing capacity can lead to unsafe results or to moving away from economy. For this reason, it is important to obtain a realistic value in the calculation of the pile bearing capacity value in terms of building safety and economy. Within the scope of the study, 8 pile loading tests methods based on direct Standard Penetration Test (SPT) data, methods based on indirect SPT data, pile loading test evaluation methods based on mathematical model and finite element method were used to obtain bearing capacity values and the methods were compared. According to the situation of the piles in different soil conditions, the most compatible methods with each other and with the average were determined for determining the bearing capacity. Considering all the test results, the closest result to the average bearing capacity value was obtained with the Bazaara \& Kurkur, Plaxis 2D and Decourt (1995) methods.
\end{abstract}

Keywords- Pile Loading Test, Ultimate Bearing Capacity, Bored Pile, Analysis Methods

İ̉letişim: halilkabaca@gmail.com (https://orcid.org/0000-0001-8700-2751)

Uzo Sadıkoğlu Inşaat Ticaret Limited Şirketi, Bursa, Türkiye

2İletişim: ivural@subu.edu.tr (https://orcid.org/0000-0003-2370-7597)

Inşaat Mühendisliği Bölümü, Sakarya Uygulamalı Bilimler Üniversitesi, Teknoloji Fakültesi, Sakarya, Türkiye

3*Sorumlu yazar İletişim: semiha.poyraz@bilecik.edu.tr (https://orcid.org/0000-0002-5449-7847)

Inşaat Bölümü, Inşaat Teknolojisi Programı, Bilecik Şeyh Edebali Üniversitesi, MYO, Bilecik, Türkiye 


\section{GİRiş}

Kentleşmenin günümüzde hızla artması ve buna paralel olarak dar alanlarda yüksek ve ağır yapıların inşa edilmesinde zemin koşullarının dikkate alınma ihtiyacı daha da önem kazanmaktadır. Zayıf zemin koşullarında imal edilen kazık temeller taşıma gücü değerlerine olumlu katkı sağlayabilmektedir. Kazıklar ile yapıdan gelen yükler derin tabakalara aktarılabilmektedir. Kazıkların taşıma gücü araştırmacılar tarafından arazi deneyleri ve laboratuvar çalışmaları ile farklı birçok yöntem ile belirlenebilmektedir. Bunun yanında kazıklar üzerinde gerçekleştirilen yükleme testlerinden elde edilen bulgular ile kazıkların taşıma gücü belirlenebilmektedir. Son yıllarda gerçeğe yakın çözüm imkânı sunması ile sonlu elemanlar analizleri de kullanılmaktadır [1].

Kazıkların taşıma gücü analizlerinde dünyada ve ülkemizde oldukça yaygın olarak Standart Penetrasyon Deneyi (SPT) verilerine dayalı yöntemler kullanılmaktadır. SPT verilerine dayanarak bazı araştırmacılar tarafından elde edilmiş bağıntılardan bazıları Meyerhof [2], Bazaara ve Kurkur [3] ve Decourt (1995) [4] tarafından önerilmiş yöntemlerdir.

Kazık taşıma gücünü belirlemek için Meyerhof, SPT verilerine dayalı olarak iri daneli zeminlerde öneride bulunmuştur. Çakma ve delme (fore) imalat tipine göre farklılık gösteren bu bağıntılar ile SPT verileri ile kazık taşıma gücü belirlenebilmektedir [2]. Bazaara ve Kurkur ise Misır zeminlerinde imal edilen delme (fore) kazıklar için belirli aralıklarda ampirik katsayılar aracılığı ile SPT verilerine dayalı bağıntılar önermişlerdir [3]. Decourt (1995) tarafından yapılan çalışmada çakma ve delme (fore) kazıklar için ince daneli veya iri daneli zeminlerde SPT değerlerine bağlı olarak ampirik katsayılar önerilmiştir [4].

SPT değerlerinin dolaylı olarak kullanıldığı kazık nihai taşıma gücü yöntemleri de mevcuttur. Bu yöntemlerden bazıları ise Tomlinson [5], O’Neil ve Reese [6] yöntemleridir. Zeminin kayma direnci parametrelerinin SPT verilerinden ampirik bağıntılarla geçiş yapılarak kazık taşıma kapasitesinin hesaplanması esasina dayanır.

Kazık taşıma gücünün belirlenmesinde kullanılmakta olan bir diğer yöntem ise kazık yükleme deneyi verileridir. Alku [7], 10 adet kazık üzerinde yapmış olduğu yükleme deneyi verilerini Teğet [8], Fuller-Hoy [9], Butler-Hoy [10], De Beer [11], Chin-Kondner [12], Decourt (1995), Brinch Hansen \%80 [13], Mazurkiewicz [14] ve Davisson [15] yöntemleri ile hesaplayarak karşılaştırmış̧ır. En büyük göçme yüklerini genelde ChinKondner ve Decourt (1995) yöntemleri, en küçüklerini ise Davisson ve De Beer yöntemleri vermiştir. ChinKondner yöntemi uygulamanın yapıldığı 10 deneyin 7'sinde en büyük göçme yükü değerini vermiş̧tir. Davisson yöntemi 10 deneyin 5'inde ve De Beer yöntemi bu deneylerin 5'inde en küçük göçme yükü değerini vermiştir. Verilerin belirsizlik parametreleri olan standart sapma, değişim katsayısı ve rastgele hata oranları göz önünde bulundurulduğunda $\% 7$ ve $\% 5$ rastgele hata oranlarıla Davisson ve De Beer yöntemlerinin \%1-2 rastgele hata oranlarına sahip olan diğer yöntemlerden daha belirsiz sonuçlar verdiği görülmüştür [7].

Geoteknik mühendisliğinde sonlu elemanlar yönteminin kullanılması son yıllarda artı̧̧ göstermektedir. Cloung ve Woodward dolguda gerilmeleri, yanal ve düşey hareketleri belirlemek amacı ile Reyes ve Deene yeraltında kayada kazı uygulamasında sonlu elemanlar yöntemini kullanmıştır [16].

İran'ın Hazar Denizi'ne yakın bölgelerinde yapılan kazık yükleme deneylerinin üç boyutlu sonlu elemanlar yöntemi ile tahkik edilmesi çalı̧̧masında sonlu elemanlar yöntemi olarak Plaxis 3D programı kullanılmıştır. 50x50 m alan içerisinde 1 metre çapında ve 7 metre boyundaki kazıklar üzerinde yapılan deneylerde sonlu elemanlar yönteminin verdiği, göçme yükü değerlerine en yakın yöntemin Bazaara ve Kurkur yöntemi olduğunu ve bu iki yöntemin de kazık yükleme deneyinden elde edilen yük-oturma grafiğine uygun olduğunu belirtmişlerdir [17].

Yapılan çalışmalardan biri beş adet aynı ortamda gerçekleştirilen geleneksel kazık yükleme deneyi ve Osterberg hücresi ile yapılan kazık yükleme deneylerinin hem birbirleriyle hem de iki boyutlu sonlu elemanlar yöntemi ile kıyaslanmasıdır. Sonlu elemanlar yöntemi uygulaması için Plaxis 2D-V8 programı kullanılmıştır. Model olarak Mohr Columb yöntemi seçilmiştir. Çalışmanın sonucunda sonlu elemanlar yönteminin Osterberg hücresi deneyine göre daha rijit bir yük-oturma grafiği verdiği, geleneksel yönteme göre ise daha fazla nihai taşıma kapasitesi verdiği sonucuna ulaşılmıştır [18].

Bu çalışmada SPT verilerine dayalı teorik yöntemler, SPT verilerine dolaylı dayalı yöntemler, tam ölçekli kazık yükleme deneyi değerlendirme yöntemleri ve sonlu elemanlar yöntemi kullanılarak kazık taşıma gücü değerleri belirlenmiştir. Ayrıca yöntemlerden elde edilen hesap sonuçları karşılaştırılarak bu dört hesap yöntemi arasındaki uyumun ortaya konulması amaçlanmıştır. 


\section{MATERYAL VE YÖNTEM}

\section{A. Materyal}

Çalışmada Türkiye'nin farklı bölgelerinde uygulanmış sekiz adet kazık yükleme deneyi verileri kullanılmıştır. Bu veriler, kazık imalatını gerçekleştiren firmalardan temin edilmiştir. İlgili bilgiler Tablo 1'de belirtilmiştir. Kazıkların tümü betonarmedir. Kazık parametreleri Betonarme Yapıların Tasarım ve Yapım Kuralları (TS500)'na uygun olarak belirlenmiştir [19].

Tablo 1. Araştırma kapsamında kullanılan kazık yükleme deneylerine ait genel bilgiler

\begin{tabular}{|c|c|c|c|c|c|c|c|}
\hline \multirow{2}{*}{$\begin{array}{c}\text { Veri / } \\
\text { Deney No }\end{array}$} & \multirow{2}{*}{ İmalatTipi } & \multirow{2}{*}{$\begin{array}{l}\text { Çalışma } \\
\text { Biçimi }\end{array}$} & \multicolumn{2}{|c|}{ Kesit Geometrisi } & \multirow{2}{*}{$\begin{array}{c}\text { Uzunluk }(\mathbf{L}) \\
(\mathbf{m})\end{array}$} & \multirow{2}{*}{ Çevre Zemini } & \multirow{2}{*}{ Uç Zemin } \\
\hline & & & Şekli & $\begin{array}{l}\text { Çap (D) / } \\
\text { Ayrit (m) }\end{array}$ & & & \\
\hline 1 & Fore & Basma & Daire & 1,20 & 36,00 & $\begin{array}{c}\text { Ayrışmış Kaya / Sert } \\
\text { Kil }\end{array}$ & Sert Kil \\
\hline 2 & Fore & Basma & Daire & 1,00 & 25,00 & $\begin{array}{c}\text { Ayrışmış Kaya / Sert } \\
\text { Kil }\end{array}$ & Sert Kil \\
\hline 3 & Fore & Çekme & Daire & 0,80 & 18,00 & $\begin{array}{c}\text { Ayrışmış Kaya / Sert } \\
\text { Kil }\end{array}$ & Sert Kil \\
\hline 4 & Fore & Basma & Daire & 1,00 & 20,00 & $\begin{array}{c}\text { Ayrışmış Kaya / Sert } \\
\text { Kil }\end{array}$ & Sert Kil \\
\hline 5 & Fore & Basma & Daire & 1,00 & 34,00 & $\begin{array}{c}\text { Ayrışmış Kaya / Sert } \\
\text { Kil }\end{array}$ & Sert Kil \\
\hline 6 & Fore & Basma & Daire & 0,80 & 26,00 & Çakı1 / Kum & Sert Kil \\
\hline 7 & Fore & Basma & Daire & 0,65 & 25,00 & Sert Kil & Sert Kil \\
\hline 8 & Çakma & Çekme & Daire & 0,65 & 30,30 & Sert Kil & Sert Kil \\
\hline
\end{tabular}

Kazıkların bulunduğu bölgelerde yapılan sondaj çalışmaları sonucunda elde edilen zemin parametreleri Tablo 2' de verilmiştir. 
Tablo 2. Deney kazıklarına ait, sonlu elemanlar hesabına ve teorik hesaplara esas teşkil eden idealize zemin özellikleri

\begin{tabular}{|c|c|c|c|c|c|c|c|c|c|}
\hline $\begin{array}{c}\text { Deney } \\
\text { Kazık No }\end{array}$ & $\begin{array}{c}\text { YASS } \\
\text { derinlik } \\
(\mathbf{m})\end{array}$ & Zemin Türü & $\begin{array}{c}\mathbf{z} \\
(\mathbf{m})\end{array}$ & $\begin{array}{c}\mathbf{c}^{\prime} \\
(\mathbf{k P a})\end{array}$ & $\begin{array}{c}\mathbf{c u}_{\mathrm{u}} \\
(\mathbf{k P a})\end{array}$ & $\begin{array}{l}\phi^{\prime} \\
\left(^{\circ}\right)\end{array}$ & $\begin{array}{c}\mathbf{E}_{50} \\
(\mathbf{m P a})\end{array}$ & $v$ & $\mathbf{N}_{\mathrm{a}(\text { ort })}$ \\
\hline \multirow[b]{2}{*}{1} & \multirow[b]{2}{*}{ $\pm 0,00$} & Ayrışmış kaya & $0,00-16,00$ & 30,53 & & 19,38 & 387,60 & 0,25 & \\
\hline & & $\begin{array}{c}\text { Kumlu siltli çok } \\
\text { sert-katı kil }\end{array}$ & $16,00-36,00$ & & 160 & & 160 & 0,495 & 38 \\
\hline \multirow{3}{*}{2} & \multirow{3}{*}{ $\pm 0,00$} & Ayrışmış kaya & $0,00-2,50$ & 22,22 & & 22,96 & 405,9 & 0,25 & \\
\hline & & $\begin{array}{l}\text { Kumlu siltli çok } \\
\text { sert-katı kil }\end{array}$ & $2,50-7,30$ & & 84 & & 84 & 0,495 & 20 \\
\hline & & $\begin{array}{c}\text { Kumlu siltli çok } \\
\text { sert- katı kil }\end{array}$ & $7,30-25,00$ & & 135 & & 135 & 0,495 & 32 \\
\hline \multirow{3}{*}{3} & \multirow{3}{*}{ $\pm 0,00$} & Ayrışmış kaya & $0,00-2,00$ & 22,22 & & 22,96 & 405,9 & 0,25 & \\
\hline & & $\begin{array}{c}\text { Kumlu siltli çok } \\
\text { sert-katı kil }\end{array}$ & $2,50-7,30$ & & 84 & & 84,0 & 0,495 & 20 \\
\hline & & $\begin{array}{c}\text { Kumlu siltli çok } \\
\text { sert-katı kil }\end{array}$ & $7,30-18,00$ & & 135 & & 135,0 & 0,495 & 32 \\
\hline \multirow{3}{*}{4} & \multirow{3}{*}{ $\pm 0,00$} & Ayrışmış kaya & $0,00-8,00$ & 18,08 & & 25,79 & 425 & 0,25 & \\
\hline & & $\begin{array}{c}\text { Kumlu siltli çok } \\
\text { katı kil }\end{array}$ & $8,00-11,00$ & & 78 & & 78 & 0,495 & 18 \\
\hline & & Kumlu siltli sert kil & $11,00-20,00$ & & 147 & & 147 & 0,495 & 34 \\
\hline \multirow{2}{*}{5} & \multirow{2}{*}{ $\pm 0,00$} & Kumlu siltli sert kil & $0,00-7,50$ & 31,09 & & 21,25 & 436,4 & 0,25 & \\
\hline & & Kumlu siltli sert kil & $7,50-34,00$ & & 185 & & 185 & 0,495 & 43 \\
\hline \multirow{2}{*}{6} & \multirow{2}{*}{ $\pm 0,00$} & Ayrışmış kaya & $0,00-24,00$ & 0 & & 38 & 50 & 0,30 & \\
\hline & & Kumlu, siltli sert kil & $24,00-26,00$ & & 180 & & 180 & 0,495 & \\
\hline \multirow{6}{*}{7} & \multirow{6}{*}{6,50} & Yumuşak kil & $0-2,80$ & & 17 & & 17 & 0,495 & 4 \\
\hline & & Orta katı kil & $2,80-8,00$ & & 26 & & 26 & 0,495 & 6 \\
\hline & & Çok katı kil & $8,00-11,00$ & & 73 & & 73 & 0,495 & 17 \\
\hline & & Çok katı kil & $11,00-19,50$ & & 91 & & 91 & 0,495 & 21 \\
\hline & & Sert kil & $19,50-22,00$ & & 130 & & 130 & 0,495 & 30 \\
\hline & & Çok katı-sert kil & $22,00-25,00$ & & 95 & & 95 & 0,495 & 22 \\
\hline \multirow{5}{*}{8} & \multirow{5}{*}{6,00} & Yumuşak kil & $0-2,95$ & & 13 & & 13 & 0,495 & 3 \\
\hline & & Katı kil & $2,95-7,65$ & & 26 & & 26 & 0,495 & 6 \\
\hline & & Çok katı kil & $7,65-15,15$ & & 69 & & 69 & 0,495 & 16 \\
\hline & & Çok katı-sert kil & $15,15-20,15$ & & 104 & & 104 & 0,495 & 24 \\
\hline & & Çok kat1-sert kil & $20,15-30,30$ & & 117 & & 117 & 0,495 & 27 \\
\hline
\end{tabular}

Sonlu elemanlar yöntemi parametreleri:

- Ince daneli zeminler için Poisson oranı 0.33, drenajsı poisson oranı suya doygun ince daneli zeminlerde otomatik olarak 0,495 alınmıştır.

- Hem fore (delme) kazıklar için hem de çakma kazıklar için kazık zemin arayüzeyi dayanım parametresi katsayısı $\left(R_{\text {int }}\right)$ 0,70 alınmıştır. Ayrışmış kayalarda ise değer 1,00 olarak alınmıştır. Bu değer, zemin dayanım parametrelerinin sadece zemin-kazık arayüzeyinde o oranda azaltıldığı anlamina gelmektedir.

- Pekleşen zemin (hardening soil) modelindeki sekant modülü $\left(\mathrm{E}_{50}{ }^{\mathrm{ref}}\right)$, elastisite modülüne eşit kabul edilmiştir.

- Pekleşen zemin (hardening soil) modelinde boşaltma-tekrar yükleme rijitlik modülü, elastisite modülünün (sekant modülünün) 3 katı alınmıştır.

- Pekleşen zemin (hardening soil) ile oluşturulan tüm zemin modellerinde power (m) değeri 1.00 alınmıştır.

\section{Eksenel Kazık Yükleme ve Çekme Deneyi:}

Kazıkların her zaman deterministik açıdan ideal bir zemin ortamında olmamasından dolayı teorik yöntemlerle her zaman taşıma kapasitesinin belirlenmesinde gerçek değere ulaşmak zordur. Bu sebeple daha gerçekçi kazık taşıma gücü değerlerini elde etmek amacıyla kazık yükleme deneyleri kullanılmaktadır. 
Kazık yükleme deneyleri kazığın üzerine ölü yük uygulanmasıyla yada kazık çevresine reaksiyon sistemi ile bir düzenek uygulanması ile gerçekleştirilmektedir. Yükler belirli zamanlarda arttırılmak yada azaltılmak suretiyle yük-oturma ilişkisi incelenerek deney yorumlanır. Basınç deneyinde ASTM D1143 [20] ve çekme deneyinde ASTM D3689 [21] standartları yaygın olarak kullanılmaktadır.

\section{B. Metot}

Çalışma kapsamında deney kazıkları, içerisinde yer aldığı zemin türü ve imalatına uygun SPT verilerine dayalı kazık taşıma gücü belirleme yöntemleri, SPT verilerine dolaylı dayalı kazık taşıma gücü belirleme yöntemleri, matematiksel modele dayalı kazık yükleme deneyi değerlendirme yöntemleri ve sonlu elemanlar yöntemi ile incelenmiş ve elde edilen sonuçlar birbirileri ile karşılaştırılmıştır. İlgili yöntemler detaylı olarak anlatılmıştır.

\section{1) Standart Penetrasyon Deneyi ile Kazık Taşıma Gücünün Bulunması Yöntemleri:}

\section{Meyerhof yöntemi:}

Meyerhof yönteminde Denk. (1)'e göre hesaplamalar yapılmaktadır [2]. İri daneli zeminlerde kullanılmıştır. Denklemde belirtilen $\mathrm{N}_{\mathrm{b}}$ : Kazık tabanından 10D kadar üstteki ve 5D kadar alttaki SPT vuruş değerlerinin ortalamasıdır. Delme (fore) kazıklarda $n_{s}=1, k=0,012, m=0,12$; Çakma kazıklarda: $n_{s}=2, k=0,04$, $\mathrm{m}=0,4$. Uç Direnci $\mathrm{q}_{\mathrm{b}}(\mathrm{MPa})=\mathrm{k} \cdot \mathrm{N}_{\mathrm{b}}$, çevre direnci $\mathrm{q}_{\mathrm{s}}(\mathrm{kPa})=\mathrm{n}_{\mathrm{s}} \cdot \mathrm{N}_{\mathrm{s}}$ olarak belirlenir. 6 no.'lu deney kazığ 1 için Tablo 3'te yöntemin uygulanma örneği belirtilmiştir.

$$
m \cdot N_{b} \leq\left(\frac{L}{D}\right)
$$

Taşıma gücü değeri 992 ton olarak elde edilir.

Tablo 3. 6 no.’lu deney kazığının Meyerhof yöntemine göre kazık taşıma gücü hesabı [2]

\begin{tabular}{|c|c|c|c|c|c|c|c|}
\hline \multirow{3}{*}{ لْ } & Tabaka & $\begin{array}{l}\text { Kalınlık } \\
\text { (m) }\end{array}$ & $\begin{array}{c}\text { Is } \\
\text { (MPa) }\end{array}$ & $\begin{array}{c}\mathbf{q u} \\
(\mathbf{M P a})\end{array}$ & $\begin{array}{l}\text { SPT- } \\
\mathbf{N}_{\text {(ort) }}\end{array}$ & $\begin{array}{c}\text { Tabaka Taşıma } \\
\text { Gücü }(\mathbf{k N})\end{array}$ & Kümülatif Taşıma Gücü $(k N)$ \\
\hline & Çakıl-kum & 24.00 & - & - & 50 & 7539.82 & 7539.82 \\
\hline & Kumlu siltli kil & 2.00 & - & - & 50 & 628.32 & 8168.14 \\
\hline \multirow{2}{*}{ 苞 } & Birim & $\begin{array}{c}\text { Alan } \\
\left(\mathbf{m}^{2}\right)\end{array}$ & $\begin{array}{c}\text { Is } \\
(\mathbf{M P a})\end{array}$ & $\begin{array}{c}\mathbf{q u}_{\mathbf{u}} \\
(\mathbf{M P a})\end{array}$ & $\begin{array}{l}\text { SPT- } \\
\mathbf{N}_{\text {(ort) }}\end{array}$ & $\begin{array}{c}\text { Uç Taşıma Gücü } \\
(\mathbf{k N})\end{array}$ & \\
\hline & Kil & 0.7854 & - & - & 50 & 1570.80 & \\
\hline
\end{tabular}

Decourt (1995) Yöntemi:

Denk. (2) ve Denk. (3)'de Decourt (1995) hesap yönteminin kullanıldığı eşitlikler verilmiştir [4]. Bu denklemlere göre ince daneli zeminlerde: $\alpha=1,0, \mathrm{k}_{\mathrm{b}}$ değeri ise çakma kazıkta 0,10 fore kazıkta 0,08 alınmıştır. İri daneli zeminlerde: $\alpha=0,5-0,6$ (hesaplarda ortalaması alınmıştır), $\mathrm{k}_{\mathrm{b}}=0,325,\left(\mathrm{~N}_{\mathrm{b}}\right)_{60}$ : Kazık tabanı çevresindeki düzeltilmiş SPT vuruş değerlerinin ortalaması ve $\left(\mathrm{N}_{\mathrm{s}}\right)_{60}$ : Hesap edilecek ilgili katman boyunca düzeltilmiş SPT vuruş ortalama değeridir. 2 no.'lu deney kazığı üzerinde yöntemin uygulanışı Tablo 4'te belirtilmiştir. Basınca çalışan fore kazığın çapı $1.00 \mathrm{~m}$, boyu $25.0 \mathrm{~m}$ ve birim çevre alanı $3.1416 \mathrm{~m}^{2}$ 'dir.

$$
\begin{aligned}
& \mathrm{q}_{\mathrm{b}}(\mathrm{MPa})=\mathrm{k}_{\mathrm{b}} \cdot\left(\mathrm{N}_{\mathrm{b}}\right)_{60} \\
& \mathrm{q}_{\mathrm{s}}(\mathrm{kPa})=\alpha \cdot\left\{2,8 \cdot\left(\mathrm{N}_{\mathrm{s}}\right)_{60}+10\right\}
\end{aligned}
$$

\begin{tabular}{|c|c|c|c|c|c|c|c|c|}
\hline \multirow{3}{*}{ 窇兽 } & Tabaka & $\begin{array}{l}\text { Kalınlık } \\
(\mathbf{m})\end{array}$ & $\begin{array}{c}\text { Is } \\
\text { (MPa) }\end{array}$ & $\begin{array}{c}\mathbf{q u} \\
(\mathbf{M P a})\end{array}$ & $\begin{array}{l}\text { SPT- } \\
\mathbf{N}_{\text {(ort) }}\end{array}$ & $\mathbf{N}_{(60)}$ & $\begin{array}{c}\text { Tabaka Taşıma } \\
\text { Gücü }(\mathbf{k N})\end{array}$ & $\begin{array}{c}\text { Kümülatif Taşıma } \\
\text { Gücü }(\mathbf{k N})\end{array}$ \\
\hline & Kumlu siltli sert kil & 4.80 & - & - & 20 & 15 & 784.14 & 1726.62 \\
\hline & Kumlu siltli sert kil & 17.70 & - & - & 32 & 24 & 4292.80 & 6019.42 \\
\hline
\end{tabular}

Tablo 4'teki veriler doğrultusunda nihai taşıma gücü 818 ton olarak bulunur.

Tablo 4. 2 no.'lu deney kazığının Decourt (1995) yöntemine göre kazık taşıma gücü hesabı [4] 


\section{Bazaara ve Kurkur Yöntemi:}

Bazaara ve Kurkur [3] delme fore kazıklar için geçerli olan bağıntıları Denk. (4) ve Denk. (5)'de ifade edilmektedir. Denklemlerde ifade edilen $\mathrm{N}_{\mathrm{b}}: \mathrm{N}_{\mathrm{b}} \leq 50$ şartı ile kazık tabanından 1D kadar üstteki ve 3,75D kadar alttaki SPT-N değerlerinin ortalamasıdır. $\mathrm{N}_{\mathrm{s}}$ : Hesap edilecek ilgili katman boyunca yapılan SPT vuruş değerlerinin ortalamasıdır. $\mathrm{n}_{\mathrm{b}}$ : 0,06-0,2 (hesaplarda ortalaması alınmıştır), $\mathrm{n}_{\mathrm{s}}:$ 2-4 (hesaplarda ortalaması alınmıştır) olarak belirlenmiştir. Yöntemin uygulanması ile ilgili örnek 2 no.'lu deney kazığı için Tablo 5'te verilmiştir. Basınca çalışan fore kazığıın çapı $1.00 \mathrm{~m}$, boyu $25.0 \mathrm{~m}$ ve birim çevre alanı $3.1416 \mathrm{~m}^{2}$ 'dir.

$$
\begin{aligned}
& \mathrm{q}_{\mathrm{b}}(\mathrm{MPa})=\mathrm{n}_{\mathrm{b}} \cdot \mathrm{N}_{\mathrm{b}} \\
& \mathrm{q}_{\mathrm{s}}(\mathrm{kPa})=\mathrm{n}_{\mathrm{s}} \cdot \mathrm{N}_{\mathrm{s}}
\end{aligned}
$$

Tablo 5 'teki veriler doğrultusunda nihai taşıma gücü 674 ton olarak bulunur.

\begin{tabular}{|c|c|c|c|c|c|c|c|c|}
\hline \multirow{3}{*}{ 导 } & Tabaka & $\begin{array}{c}\text { Kalınlık } \\
(\mathbf{m})\end{array}$ & $\begin{array}{c}\text { Is } \\
\text { (MPa) }\end{array}$ & $\begin{array}{c}\mathbf{q u}_{\mathbf{u}} \\
(\mathbf{M P a})\end{array}$ & $\begin{array}{l}\text { SPT- } \\
\mathbf{N}_{\text {(ort) }}\end{array}$ & $\mathbf{N}_{(60)}$ & $\begin{array}{c}\text { Tabaka Taşıma } \\
\text { Gücü }(\mathbf{k N})\end{array}$ & $\begin{array}{c}\text { Kümülatif Taşıma } \\
\text { Gücü }(k N)\end{array}$ \\
\hline & Siltli kil & 4.80 & - & - & 20 & - & 603.19 & 1545.66 \\
\hline & Kumlu siltli kil & 17.70 & - & - & 32 & - & 3558.80 & 5104.46 \\
\hline \multirow{2}{*}{ 可苞 } & Birim & $\begin{array}{c}\text { Alan } \\
\left(\mathbf{m}^{2}\right)\end{array}$ & $\begin{array}{c}\text { Is } \\
\text { (MPa) }\end{array}$ & $\begin{array}{c}\mathbf{q u}_{\mathbf{u}} \\
(\mathbf{M P a})\end{array}$ & $\begin{array}{l}\text { SPT- } \\
\mathbf{N}_{(\text {ort })} \\
\end{array}$ & $\mathbf{N}_{(60)}$ & $\begin{array}{c}\text { Uç Taşıma Gücü } \\
(\mathbf{k N})\end{array}$ & \\
\hline & Kil & 0.7854 & - & - & 32 & - & 1507.96 & \\
\hline
\end{tabular}

Tablo 5. 2 no.'lu deney kazı̆̆ının Bazaara ve Kurkur (1989) yöntemine göre kazık taşıma gücü hesabı [3]

2) SPT Deneyi Verilerinin Dolaylı Kullanılmasıyla Kazık Taşıma Gücünün Bulunması Yöntemleri:

O'Neill ve Reese yöntemi:

O’Neill ve Reese [6] tarafından ' $\alpha_{\mathrm{u}}$ ” adezyon faktörü fore kazıklar için Denk. (6) ve Denk. (7)' deki gibi bağıntı önerilmiştir $\left(c_{\mathrm{u}}\right.$ : drenajsız kayma direnci $\left(\mathrm{kN} / \mathrm{m}^{2}\right), \mathrm{p}_{\mathrm{a}}$ : Atmosfer basıncı $\left(101.3 \mathrm{kN} / \mathrm{m}^{2}\right)$ ve $\alpha_{\mathrm{u}}$ : adezyon faktörü). 5 no.'lu deney kazığ üzerinde yöntemin uygulanışı Tablo 6' da belirtilmiştir. Basınca çalışan fore kazı̆̆ın çap1 $1.00 \mathrm{~m}$, boyu $34.0 \mathrm{~m}$ ve birim çevre alanı $3.1416 \mathrm{~m}^{2}$ ' dir.

$$
\begin{aligned}
\frac{c_{u}}{p_{a}} & \leq 1,5 \quad \alpha_{u}=0,55 \\
1,5 & \leq \frac{c_{u}}{p_{a}} \leq 2,5 ; \quad \alpha_{u}=0,55-0,1 \cdot\left(\frac{c_{u}}{p_{a}}-1,5\right)
\end{aligned}
$$

\begin{tabular}{|c|c|c|c|c|c|c|c|c|c|}
\hline \multirow{3}{*}{ ن } & Tabaka & $\begin{array}{c}\text { Kalınlık } \\
(\mathbf{m})\end{array}$ & $\begin{array}{c}\text { Is } \\
\text { (MPa) }\end{array}$ & $\begin{array}{c}\mathbf{q u}_{\mathrm{u}} \\
(\mathbf{M P a})\end{array}$ & $\begin{array}{l}\text { SPT- } \\
\mathbf{N}_{(\text {ort })}\end{array}$ & $\begin{array}{c}\mathbf{c}_{\mathrm{u}} \\
(\mathbf{k P a})\end{array}$ & $\alpha$ & $\begin{array}{c}\text { Tabaka Taşıma } \\
\text { Gücüi }(\mathbf{k N})\end{array}$ & $\begin{array}{c}\text { Kümülatif Taşıma } \\
\text { Gücü }(\mathbf{k N})\end{array}$ \\
\hline & Kumlu siltli kil & 7.50 & - & - & 38 & 164 & 0.538 & 2079.32 & 2079.32 \\
\hline & Kumlu siltli kil & 26.50 & - & - & 43 & 185 & 0.537 & 7968.42 & 10047.74 \\
\hline \multirow{2}{*}{ 芦异: } & Birim & $\begin{array}{c}\text { Alan } \\
\left(\mathbf{m}^{2}\right)\end{array}$ & $\begin{array}{c}\text { Is } \\
(\mathbf{M P a})\end{array}$ & $\begin{array}{c}\mathbf{q u}_{\mathbf{u}} \\
(\mathbf{M P a})\end{array}$ & $\begin{array}{l}\text { SPT- } \\
\mathbf{N}_{(\text {ort })}\end{array}$ & \multicolumn{2}{|c|}{$\begin{array}{c}\mathbf{c}_{\mathrm{u}} \\
(\mathbf{k P a})\end{array}$} & $\begin{array}{c}\text { Uç Taşıma Güicü } \\
(\mathbf{k N})\end{array}$ & \\
\hline & Kil & 0.7854 & - & - & 43 & \multicolumn{2}{|c|}{165} & 941.65 & \\
\hline
\end{tabular}

Tablo 6'daki veriler doğrultusunda nihai taşıma gücü 1120 ton olarak bulunur.

Tablo 6. 5 no.’lu deney kazığı O’Neill ve Reese yöntemine göre taşıma gücü hesabı [6]

\section{Tomlinson Yöntemi:}

Çevre sürtünme direnci iri daneli zeminlerde düşey efektif gerilmeye bağlı olarak Denk. (8)'de belirtilmiştir [5]. $\mathrm{f}_{\mathrm{s}, \text { ult }}$ : Birim alan düşen nihai çevre taşıma direnci $\left(\mathrm{kN} / \mathrm{m}^{2}\right), \sigma{ }_{0}$ : Hesap yapılan tabakaya ait ortalama düşey efektif gerilme $\left(\mathrm{kN} / \mathrm{m}^{2}\right), \quad \mathrm{K}_{\mathrm{s}}$ : Yanal toprak basınc1 katsayısı (Birimsiz), $\delta: z e m i n-k a z ı k$ arası sürtünme açısıdır ( ${ }^{\circ}$ : Derece), $\mathrm{K}_{0}$ : sükunetteki toprak basıncıdır. Tomlinson tarafından $\mathrm{K}_{\mathrm{s}}$ yanal toprak basıncı katsayısının $\mathrm{K}_{0}$ sükunetteki toprak basıncı katsayısına olan oranı tarafından sunulmuş öneriler Tablo 7'de belirtilmiştir [5]. 6 no.'lu deney kazığı üzerinde yöntemin uygulanışı Tablo 8'de belirtilmiştir. Basınca çalışan fore kazığın çapı $1.20 \mathrm{~m}$, boyu $26.00 \mathrm{~m}$ ve birim çevre alanı $3.1416 \mathrm{~m}^{2}$ 'dir.

$$
f_{s, u l t}=\sigma_{0}^{\prime} \cdot K_{s} \cdot \tan \delta
$$






Tablo 7. İri daneli zeminlerde $\mathrm{K}_{s} / \mathrm{K}_{0}$ önerileri [5]

\begin{tabular}{cc}
\hline Kazık imal şekli & $\mathbf{K}_{\mathbf{s}} / \mathbf{K}_{\mathbf{0}}$ \\
\hline Çakma kazıklar (Büyük sıkıştırma etkili) & $1 \sim 2$ \\
Çakma kazıklar (Küçük sıkıştırma etkili) & $0.75 \sim 1.25$ \\
Betonarme fore (delme) kazıklar & $0.75 \sim 1.00$ \\
Su jeti kullanılarak imal edilmiş kazıklar & $0.50 \sim 0.70$ \\
\hline
\end{tabular}

Tablo 8'deki veriler doğrultusunda nihai taşıma gücü 673 ton olarak bulunur.

Tablo 8. 6 no.'lu deney kazığının Tomlinson yöntemine göre taşıma gücü hesabı [5]

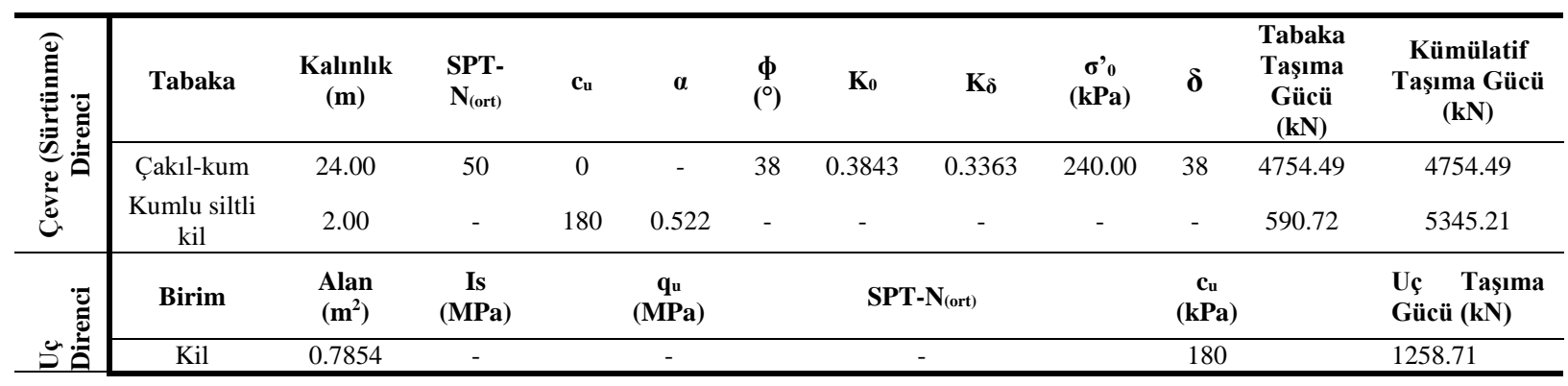

3) Matematiksel Modele Dayalı Kazık Yükleme Deneyi Değerlendirme Yöntemleri;

\section{Chin-Kondner Yöntemi:}

Chin, Kondner'in 1963 ’te gerilme-deformasyon üzerine yaptığı çalışmayı tüm kazıklar için genelleyerek, göçme yüküne ulaşmamış kazık yükleme deneylerinin ekstrapolasyon ile yorumlanması üzerine bir yöntem geliştirmiştir [12]. Dağılım gösteren noktalar ideal bir doğru üzerinde toplanır. Doğrunun oturma/yük eksenini kestiği nokta $C_{2}$, eğimi ise $C_{1}$ ' dir. Doğrunun eğiminin tersi, Denk. (9)'da gösterildiği gibi kazığın göçme yükünü vermektedir. Yöntemin 1 no.'lu deney kazığı üzerinde uygulanışı Şekil 1'de gösterilmiştir.

$$
Q_{u l t}=\frac{1}{c_{1}}
$$

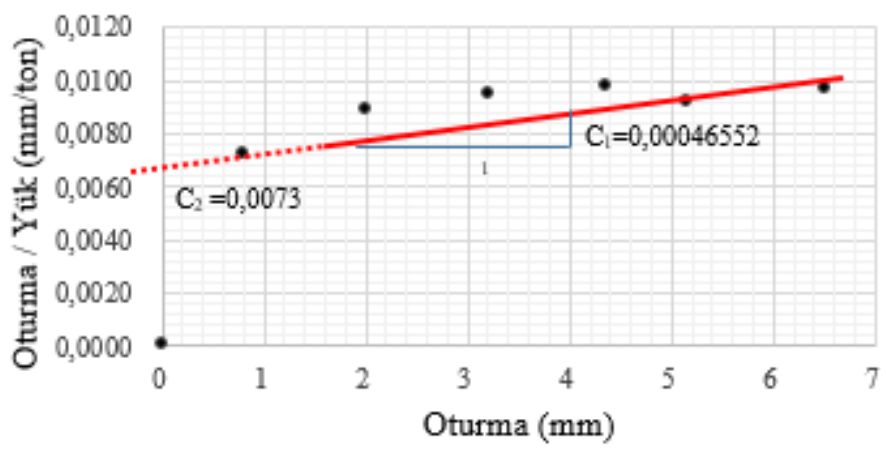

Şekil 1. Chin-Kondner (1970) yönteminin 1 no.'lu deney kazı̆̆ı üzerinde uygulanması [12]

Decourt (1999) yöntemi:

Decourt (1999) yönteminde her kademede yer alan yük değeri, o değere karşıllk gelen oturma değerine bölünmektedir. Bulunan değerler ile yük değerleri bir grafik üzerinde dağılım halinde gösterilmektedir [23]. Dağılımın lineer olan nokta değerleri yaklaşık bir doğru üzerinde toplanır. Bu doğrunun eğimi $C_{1}$, yük/oturma eksenini kestiği noktanın niceliğine $\mathrm{C}_{2}$ dersek, göçme yükü değeri Denklem 7 ile hesaplanır. 1 no.'lu deney kazığı üzerinde yöntemin uygulanış1 Şekil 2'de gösterilmiştir. 


\begin{tabular}{|c|c|c|}
\hline & $\begin{array}{l}\text { BŞEÜ Fen Bilimleri Dergisi } \\
8(2), 531-546,2021\end{array}$ & $\begin{array}{r}\text { BSEU Journal of Science } \\
\text { https://doi.org/10.35193/bseufbd.856498 }\end{array}$ \\
\hline $\begin{array}{l}\text { ECIK SEYH EDEBALI } \\
|I| V E R S I T E S \mid\end{array}$ & & 2458-7575 (https://dergipark.org.tr/tr/pub/bseufbd) \\
\hline
\end{tabular}

$$
Q_{u l t}=\frac{c_{2}}{c_{1}}
$$

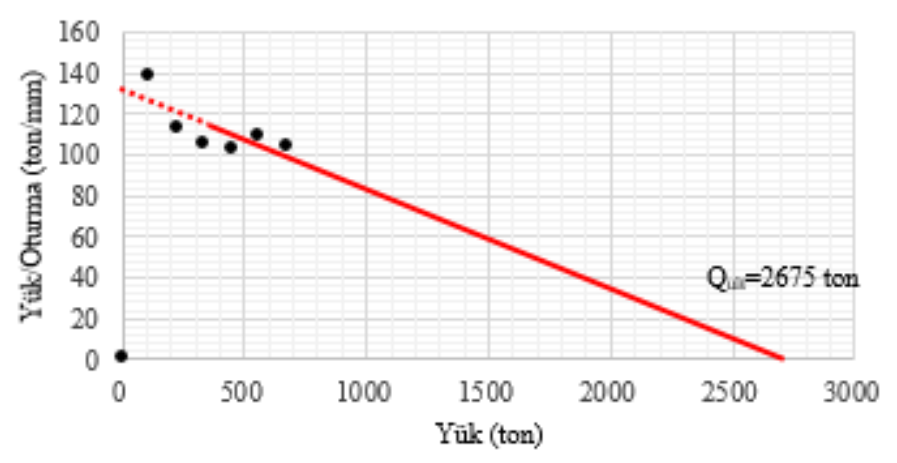

Şekil 2. Decourt (1999) yönteminin 1 no.'lu deney kazığında uygulanması [24]

\section{Özkan-Alku Yöntemi:}

Bu yöntemde esas olan yük-oturma grafiğini çift fonksiyon olarak belirlemektir. Göçme (nihai) yükünün bulunması da son fonksiyon aracılı̆̆ıla yapılır [7]. Son fonksiyon için Şekil 3'te gösterildiği gibi $\sqrt{Q} / \delta$ - Q (yükün karekökü bölü oturma - yük) grafiği çizilir. Bu dağllımdaki noktalar belli bir değerden sonra doğrusal halde ilerlemektedir. Doğrusal nokta değerleri birleștirilerek oluşturulan doğrunun eğimi ve düşey ekseni kestiği nokta bulunur. Düşey ekseni kesen nokta Özkan-Alku göçme yükünü verir. 1 no.'lu deney kazığı üzerinde yöntemin uygulanışı Şekil 3’te belirtilmiştir.

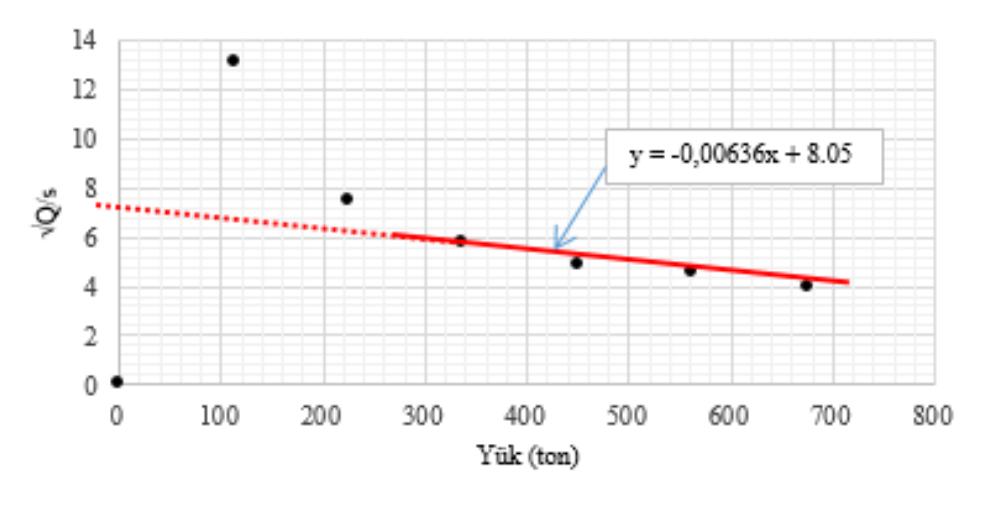

Şekil 3. 1 no.'lu deney kazığı üzerinde Özkan-Alku yönteminin uygulanışı [7]

\section{4) Sonlu Elemanlar Yöntemi ile Kazık Nihai Taşıma Gücünün Bulunması;}

Çalışmada sonlu elemanlar yöntemi ile kazık taşıma gücünün belirlenmesinde Plaxis 2D yazılımı kullanılmıştır [22]. Bu yazılım, hesaplamalarını karmaşık sonlu elemanlar problemlerini kullanıcının belirlediği malzeme modelleri ve sınır koşullarına dayanarak iki boyutta gerçekleştirmektedir. Kazık yükleme deneylerini bilgisayar yazılımı üzerinde temsil etmek amacıyla eksenel simetrik (axisymmetric) model kullanılmıştır. Şekil 4'te 1 no.'lu deney kazığı üzerinde sonlu elemanlar yönteminin uygulanışı gösterilmektedir. Grafikte yük-oturma eğrisinin keskin dönüş yapan eğri olması sebebiyle plastikleşmeye başladığı yük göçme yükü değeri kabul edilmiştir. 


\begin{tabular}{|c|c|c|}
\hline & $\begin{array}{l}\text { BŞEÜ Fen Bilimleri Dergisi } \\
8(2), 531-546,2021\end{array}$ & $\begin{array}{r}\text { BSEU Journal of Science } \\
\text { https://doi.org/10.35193/bseufbd.856498 }\end{array}$ \\
\hline $\begin{array}{l}\text { - BILECIKSEYH EDEE } \\
\text { ONIVERSITE }\end{array}$ & & 2458-7575 (https://dergipark.org.tr/tr/pub/bseufbd) \\
\hline
\end{tabular}

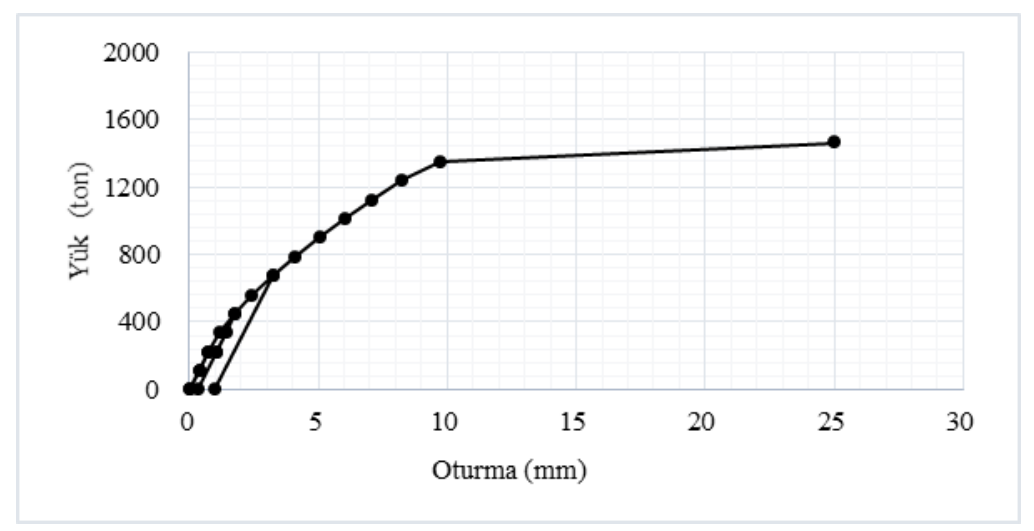

Şekil 4. Sonlu elemanlar (Plaxis 2D) yönteminin 1 no.'lu deney kazığında uygulanması [22]

\section{ARAŞTIRMA BULGULARI}

8 adet deney kazığı üzerinde Standart Penetrasyon Deneyi verilerine dayalı Decourt (1995), Bazaara ve Kurkur ve Meyerhof, Standart Penetrasyon Deneyi verilerine dolaylı dayalı O’Neill ve Reese, Tomlinson yöntemleri, Matematiksel modele dayalı kazık yükleme deneyi değerlendirme yöntemleri Chin-Kondner, Decourt (1999), Özkan-Alku ve Sonlu elemanlar yöntemi ile yapılan taşıma gücü analizleri ortalama değerleri Şekil 5’te belirtilmiştir.

Șekil 5(a)'da 1 no.'lu deney kazığı üzerinde yapılan analiz sonuçları değerlendirildiğinde ortalama taşıma kapasitesi değeri 1816 ton çıkmaktadır. Bu değere en yakın yöntemin 1691 ton taşıma kapasitesi değeri ile ÖzkanAlku yöntemi olduğu görülmektedir. En yüksek göçme değerini 2635 ton ile Decourt (1999) yöntemi vermiştir. En düşük taşıma kapasitesi değeri ise 135 ton olup Plaxis 2D sonlu elemanlar analizi ile elde edilmiştir.

Şekil 5(b)'de 2 no.'lu deney kazığı üzerinde yapılan analiz sonuçları değerlendirildiğinde ortalama taşıma kapasitesi 867 ton elde edilmiştir. Ortalama değere en yakın yöntemin Decourt (1995) olduğu görülmektedir. Ortalama değere en uzak yüksek göçme yükü veren yöntem 1140 ton değeri ile Chin-Kondner yöntemidir. Ortalama taşıma kapasitesi değerine en uzak düşük göçme yükü veren yöntem Standart Penetrasyon Deneyi verilerine dolaylı dayalı O'Neill ve Reese yöntemi olup 638 ton taşıma kapasitesi değeri elde edilmiş̧ir.

Şekil 5(c)'de 3 no.'lu deney kazığı üzerinde yapılan analiz sonuçları değerlendirildiğinde ortalama göçme yükü değeri 342 ton olarak bulunmuştur. Bu ortalama değere en yakın göçme yükünü 337 ton değeri ile O'Neill ve Reese yöntemi vermiştir. 272 ton taşıma kapasitesi değeri ile Özkan-Alku yöntemi en düşük değeri vermiştir. Decourt (1999) yöntemi en yüksek değeri vermiş olup bu değer 425 ton taşıma kapasitesi değeri olarak elde edilmiştir.

Şekil 5(d)'de 4 no.'lu deney kazı̆ğ üzerinde yapılan analizlerde 806 ton ortalama taşıma kapasitesi elde edilmiştir. Bu değere en yakın 770 ton taşıma kapasitesi değeri ile Özkan-Alku yöntemi ile ulaşılmıștır. Ortalama taşıma kapasitesi en uzak ve yüksek değeri Chin-Kondner yöntemi vermiş olup bu değer 1075 ton'dur. O'Neill ve Reese 646 ton taşıma kapasitesi değeri ile en düşük sonucu vermiştir.

Şekil 5(e)'de 5 no.'lu deney kazığı üzerinde yapılan analizler sonucunda ortalama taşıma kapasitesi 1247 ton olarak bulunmuştur. 1325 ton taşıma kapasitesi değeri ile ortalamaya en yakın değerin Decourt (1999) yöntemi olduğu belirlenmiştir. En düşük göçme değerini 885 ton ile Özkan-Alku yöntemi, en yüksek göçme yükü değerini ise 1500 ton ile Chin-Kondner yöntemi vermiştir.

Şekil 5(f)'de 6 no.'lu deney kazığı analiz sonuçlarına göre ortalama taşıma kapasitesi 794 ton elde edilmiştir. Bu ortalama değere en yakın 755 ton ile taşıma kapasitesi değeri ile Decourt (1995) ve Decourt (1999) yöntemleri olduğu görülmüştür. En yüksek taşıma kapasitesi değeri veren yöntem Meyerhof yöntemi olup 992 ton sonuç elde edilmiştir. En düşük değeri veren yöntem ise 673 ton taşıma kapasitesi değeri ile Tomlinson yöntemidir.

Şekil 5(g)'de 7 no.'lu deney kazığı üzerinde gerçekleştirilen analizler çalışmalarında ortalama değer 298 ton olarak bulunmuştur. Bu ortalama değere en yakın göçme yükü veren değer Plaxis $2 \mathrm{D}$ analiz yöntemidir. En düşük göçme yükünü 211 ton değeri ile O'Neill ve Reese yöntemi, en yüksek göçme yükünü 380 ton değeri ile Chin-Kondner yöntemi vermiştir. 


\begin{tabular}{|c|c|c|}
\hline & $\begin{array}{l}\text { BŞEÜ Fen Bilimleri Dergisi } \\
8(2), 531-546,2021\end{array}$ & $\begin{array}{r}\text { BSEU Journal of Science } \\
\text { https://doi.org/10.35193/bseufbd.856498 }\end{array}$ \\
\hline $\begin{array}{l}\text { BiLECIKSEYYH EDEBALI } \\
\text { UNIVERSITESI }\end{array}$ & & 2458-7575 (https://dergipark.org.tr/tr/pub/bseufbd) \\
\hline
\end{tabular}

Şekil 5(h)'de 8 no.'lu deney kazı̆̆ı üzerinde gerçekleştirilen analizlerde ortalama taşıma gücü 294 ton bulunmuştur. Bu değere en yakın taşıma kapasitesi değeri veren yöntem Decourt (1995) yöntemi olup 303 ton'dur. En yüksek taşıma gücü değeri veren yöntem ise 425 ton değeri ile Tomlinson yöntemidir. En düşük taşıma gücü değeri ise 209 ton olup Özkan-Alku yöntemi ile elde edilmiştir.

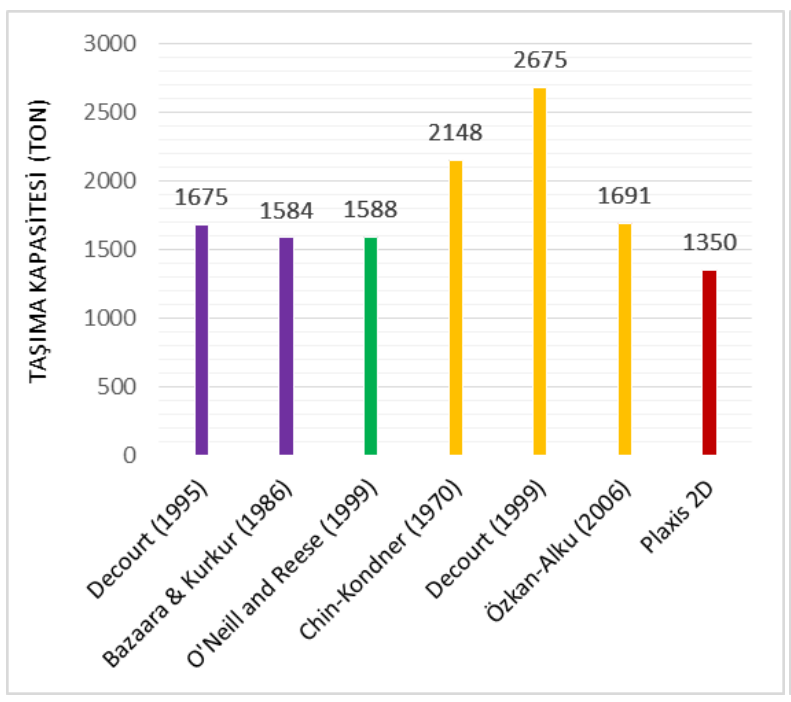

(a)

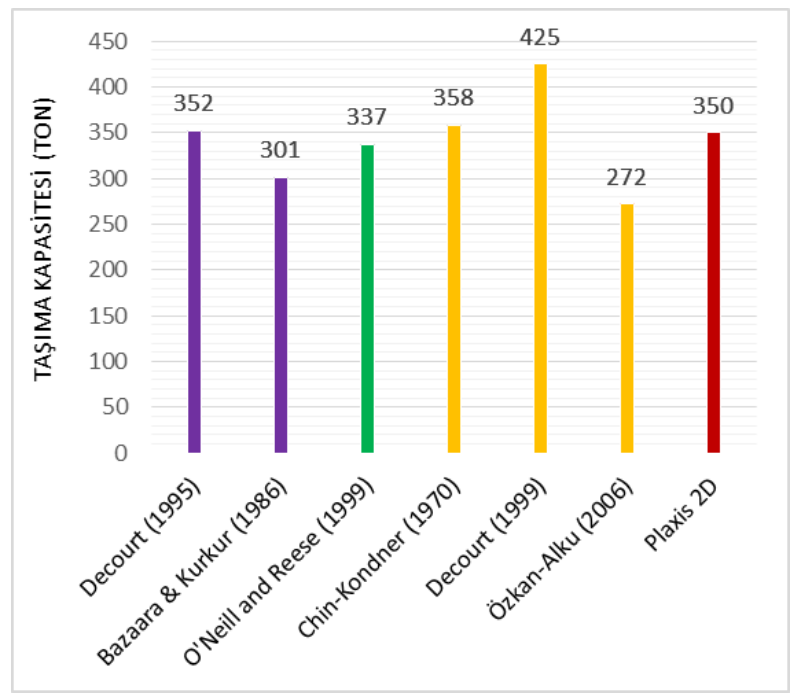

(c)

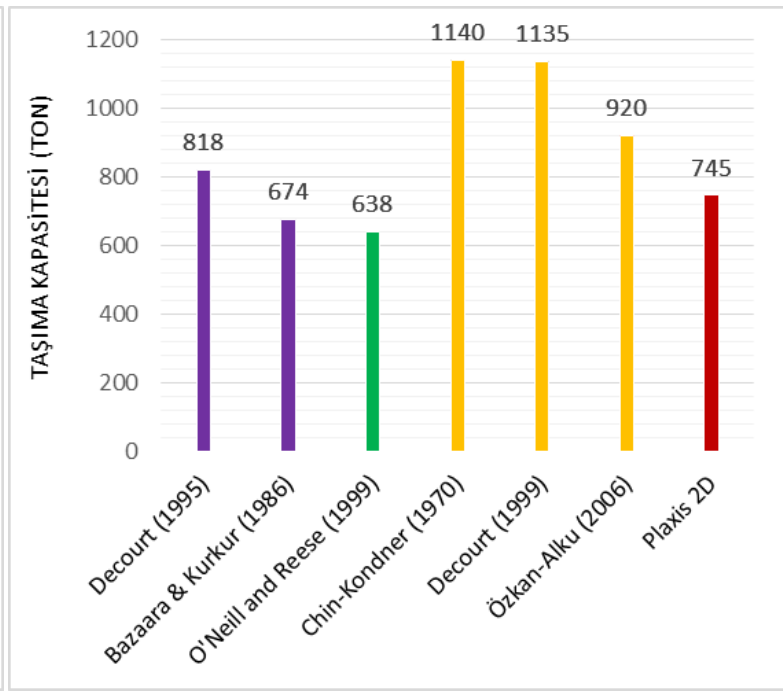

(b)

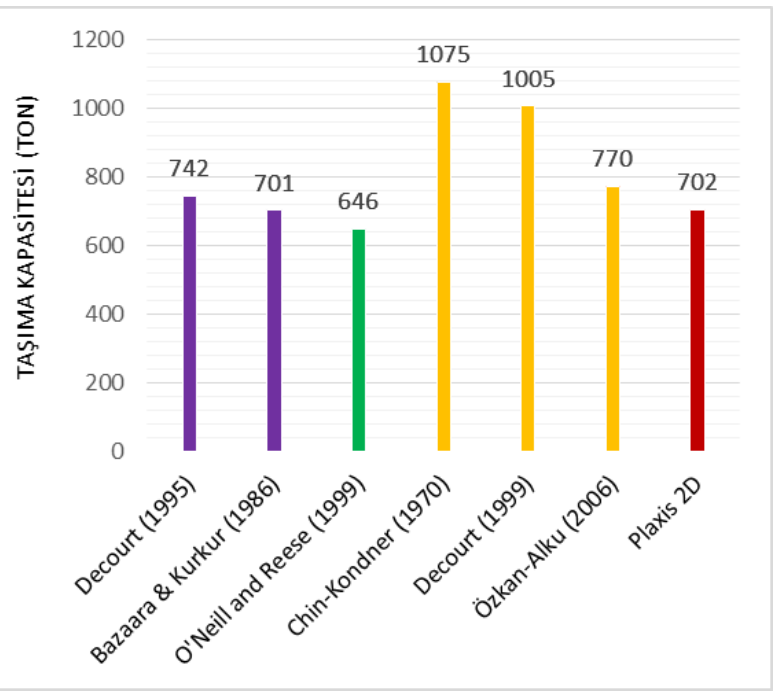

(d) 

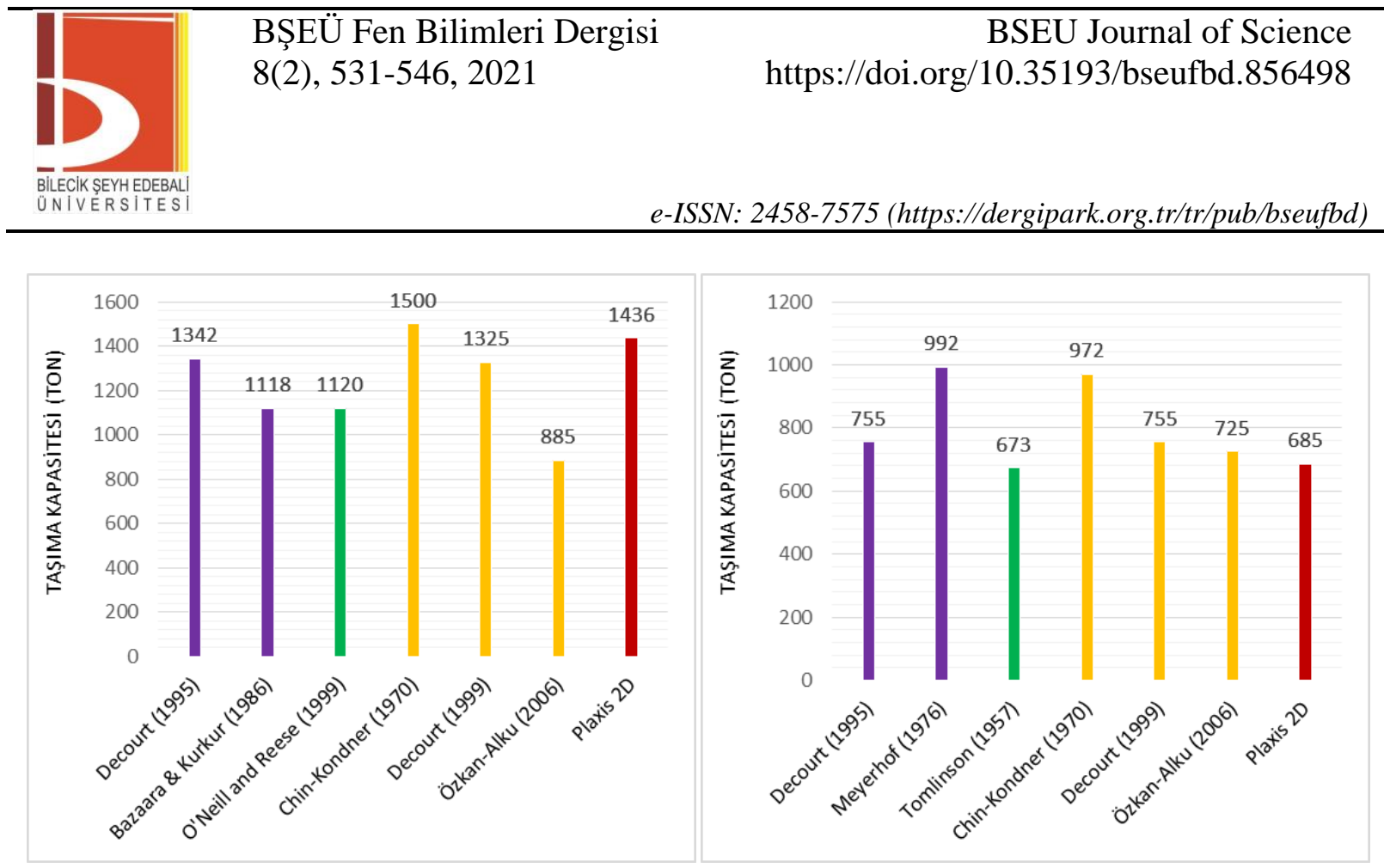

(e)

(f)

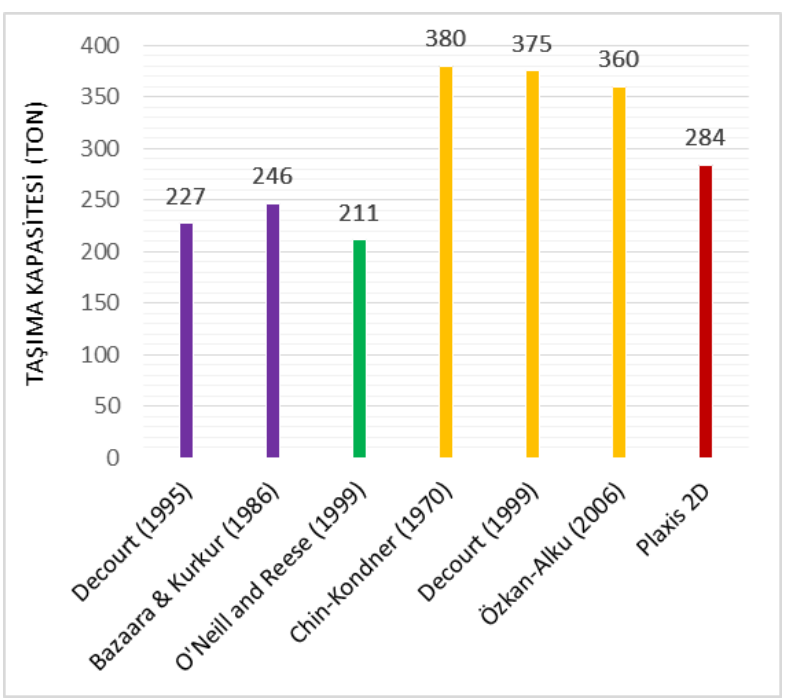

(g)

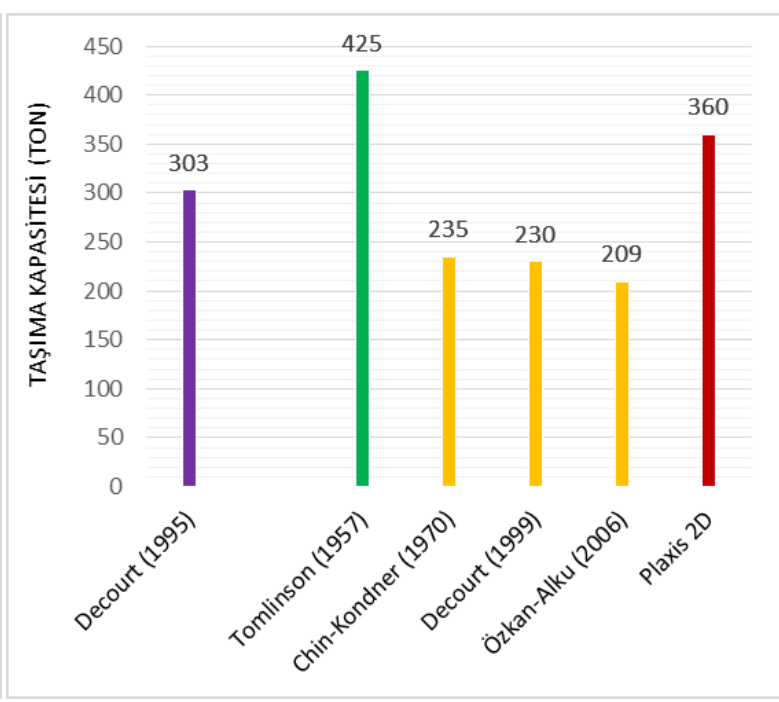

(h)

Şekil 5. (a) 1 no.'lu deney kazığı (b) 2 no.'lu deney kazığı (c) 3 no.'lu deney kazığı (d) 4 no.'lu deney kazığı (e) 5 no.'lu deney kazı̆̆ı (f) 6 no.'lu deney kazığı (g) 7 no.'lu deney kazığı (h) 8 no.'lu deney kazığı analizleri sonuçları

SPT verilerine dayalı Decourt (1995), Bazaara ve Kurkur ve Meyerhof yöntemleri ile elde edilen her bir deney kazığı için taşıma kapasitesi değerinin aynı kazıktaki tüm yöntemlerin ortalama taşıma kapasitesi değerine oranı Şekil 6'da verilmiştir. Decourt (1995) yöntemi ortalama değerin 1 no.lu deney kazığı üzerinde 0,92 katı, 2 no.lu deney kazığı üzerinde 0,94 katı, 3 no.'lu deney kazığı üzerinde 1,03 katı, 4 no.'lu deney kazığ1 üzerinde 0,92 katı, 5 no.'lu deney kazığı üzerinde 1,08 katı değeri ile Bazaara \& Kurkur yöntemine göre daha yakın sonuç vermiştir. 6 no.'lu deney kazığı üzerinde gerçekleştirilen hesaplarda ortalama değere en yakın değeri 1,24 katı ile Meyerhof yöntemi vermiştir. 6 no.'lu deney kazığı üzerinde gerçekleştirilen taşıma kapasitesi hesaplarında en yakın değeri ortalamanın 0,95 katı ile Decourt (1995) yöntemi vermiştir. Ardından ortalama taşıma kapasitesinin 1,24 katı Meyerhof yöntemi ve 1,25 katı Bazaara ve Kurkur yöntemi ile elde edilmiştir. 8 no.'lu deney kazığ 1 üzerinde Decourt (1995) yöntemiyle gerçekleştirilen taşıma kapasitesi hesabında ortalama değerin 1,03 katı değer bulunmuştur. 


\begin{tabular}{|c|c|c|}
\hline & $\begin{array}{l}\text { BŞEÜ Fen Bilimleri Dergisi } \\
8(2), 531-546,2021\end{array}$ & $\begin{array}{r}\text { BSEU Journal of Science } \\
\text { https://doi.org/10.35193/bseufbd.856498 }\end{array}$ \\
\hline $\begin{array}{l}\text { BiLECIKSEYYH EDEBALI } \\
\text { UNIVERSITESI }\end{array}$ & & 2458-7575 (https://dergipark.org.tr/tr/pub/bseufbd) \\
\hline
\end{tabular}

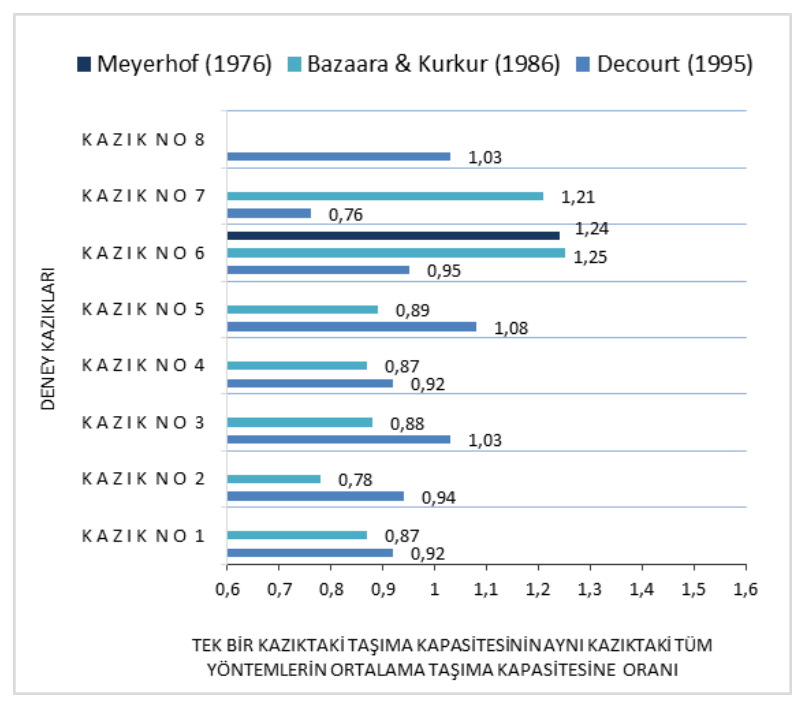

Şekil 6. SPT verilerine dayalı yöntemlerin tek bir kazıktaki taşıma kapasitesinin aynı kazıktaki tüm yöntemlerin ortalama taşıma kapasitesine oranları

SPT verilerine dolaylı dayalı O’Neill ve Reese, Tomlinson yöntemleri ile elde edilen her bir deney kazığı için taşıma kapasitesi değerinin aynı kazıktaki tüm yöntemlerin ortalama taşıma kapasitesi değerine oranı Şekil 7'de verilmiştir. Buna göre O’Neill ve Reese yöntemi ile kazık taşıma kapasitesi hesap sonuçları ortalama değerlerin 1 no.'lu deney kazığı üzerinde 0,87 katı, 2 no.'lu deney kazı $\breve{g ̆}_{1}$ üzerinde 0,73 katı, 3 no.'lu deney kazı $\breve{g ̆}_{1}$ üzerinde 0,98 katı, 4 no.'lu deney kazığ kazığı üzerinde 0,70 katı değer elde edilmiştir. Tomlinson yöntemi ile 6 no.'lu deney kazığ taşıma kapasitesi hesaplamasında ortalamanın 0,84 katı, 8 no.'lu deney kazı̆̆ında ise ortalamanın 1,44 katı değer elde edilmiştir.

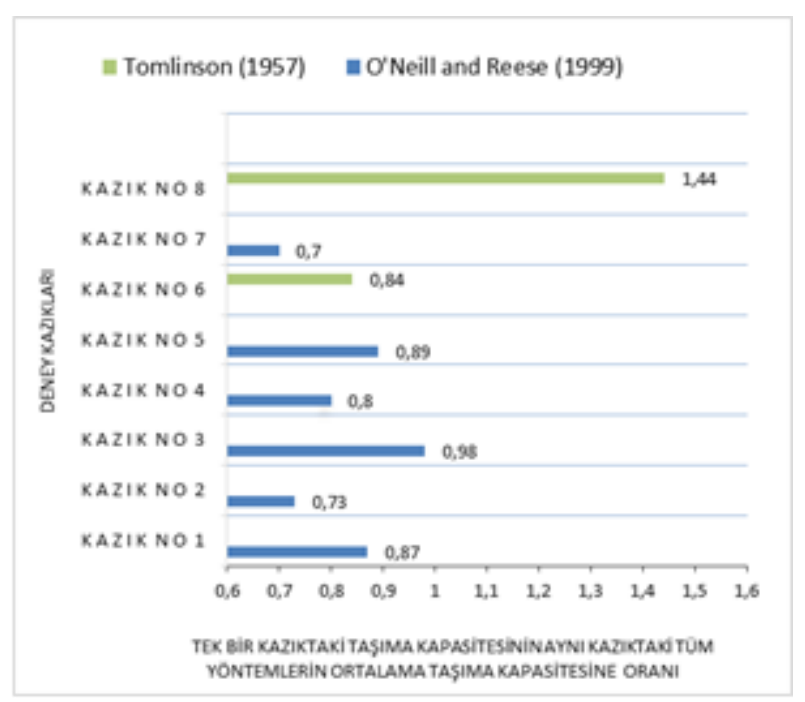

Şekil 7. SPT verilerine dolaylı dayalı yöntemlerin tek bir kazıktaki taşıma kapasitesinin aynı kazıktaki tüm yöntemlerin ortalama taşıma kapasitesine oranları

Matematiksel modele dayalı kazık yükleme deneyi değerlendirme yöntemleri Chin-Kondner, Decourt (1999), Özkan-Alku yöntemleri ile elde edilen her bir deney kazığı için taşıma kapasitesi değerinin aynı kazıktaki tüm yöntemlerin ortalama taşıma kapasitesi değerine oranı Şekil 8'de verilmiştir. Buna göre 1 no.'lu deney kazığında ortalamanın 0,93 katı ile en yakın değeri Özkan-Alku yöntemi vermiştir. Ardından Chin-Kondner yöntemi ortalamanın 1,18 katı değeri vermiştir. 1,47 katı değer ile en uzak değeri Decourt (1999) yöntemi vermiştir. 2 no.'lu deney kazığında ortalamanın 1,06 katı ile ortalamaya en yakın değeri Özkan-Alku yöntemi vermiştir. Decourt (1999) yöntemi ortalamanın 1,3 katı değer, Chin-Kondner ise ortalamanın 1,31 katı değer vermiştir. 3 no.'lu kazıkta Chin-Kondner yöntemiyle ortalamanın 1,04 katı ile en yakın değer elde edilmiştir. 
Ardından Özkan-Alku yöntemi ile ortalamanın 0,79 katı, Decourt (1999) yöntemi ile 1,24 katı değerler elde edilmiştir. 4 no.'lu deney kazı̆̆ı üzerinde yapılan taşıma kapasitesi hesaplarında ortalamanın 0,95 katı ile en yakın değer Özkan-Alku yöntemiyle en uzak değer ise ortalamanın 1,33 katı ile Chin-Kondner ile elde edilmiştir. Decourt (1999) yöntemi ile ortalamanın 1,24 katı değer elde edilmiştir. 5 no.'lu deney kazığı üzerinde yapılan taşıma kapasitesi hesaplarında ortalamanın 1,06 katı ile en yakın değer Decourt (1999) yöntemi ile elde edilmiştir. Ardından Chin-Kondner yöntemiyle ortalamanın 1,2 katı ve Özkan-Alku yöntemiyle 0,7 katı ile en uzak değer elde edilmiştir. 6 no.'lu deney kazı̆̆ı üzerinde gerçekleştirilen hesaplarda ortalamaya en yakın değer 0,95 katı ile Decourt (1999) yöntemiyle elde edilmiştir. En uzak değer ise ortalamanın 1,22 katı ile Chin-Kondner yöntemiyle elde edilmiştir. Özkan-Alku yöntemiyle ise ortalama değerin 0,91 katı değer elde edilmiştir. 7 no.'lu deney kazığ üzerinde gerçekleştirilen taşıma kapasitesi hesabında ortalamaya en yakın değer 1,2 katı ile Özkan-Alku yöntemiyle elde edilmiştir. En uzak değer ise 1,27 katı ile Chin-Kondner yöntemiyle elde edilmiştir. Decourt (1999) yöntemi ise ortalamanın 1,25 katı değer vermiştir. 8 no.'lu deney kazı ğı ortalama taşıma kapasitesi değerine en yakın değer 0,79 katı ile Chin-Kondner yöntemi ile elde edilmiştir. En uzak değer ise 0,71 katı ile Özkan-Alku yöntemiyle elde edilmiştir. Decourt yöntemi ise 0,78 katı değer vermiştir.

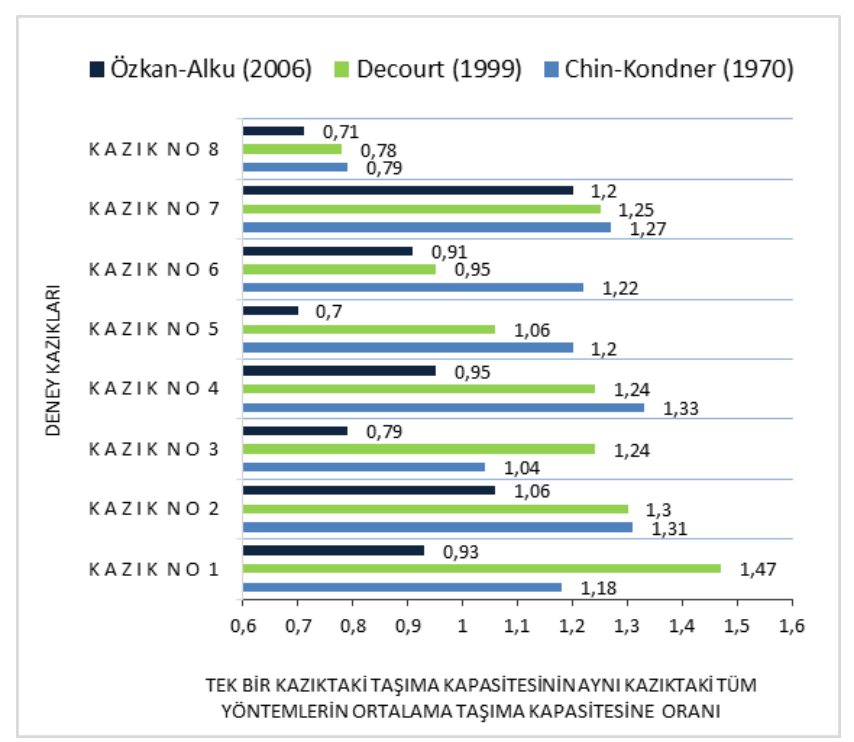

Şekil 8. Matematiksel modele dayalı kazık yükleme deneyi değerlendirme yöntemlerinin tek bir kazıktaki taşıma kapasitesinin aynı kazıktaki tüm yöntemlerin ortalama taşıma kapasitesine oranları

Sonlu elemanlar yöntemi (Plaxis 2D) ile elde edilen her bir deney kazığı için taşıma kapasitesi değerinin aynı kazıktaki tüm yöntemlerin ortalama taşıma kapasitesi değerine oranı Şekil 9'da verilmiştir. Sonlu elemanlar yöntemiyle gerçekleştirilen taşıma kapasitesi hesaplamalarında 1 no.lu deney kazığında ortalamanın 0,74 katı, 2 no.'lu deney kazığı üzerinde 0,85 katı, 3 no.'lu deney kazığında 1,02 katı, 4 no.'lu deney kazığında 0,87 katı, 5 no.'lu deney kazığında 1,15 katı, 6 no.'lu deney kazığında 1,15 katı, 6 no.'lu deney kazığında 0,86 katı, 7 no.'lu deney kazığında 0,95 katı, 8 no.'lu deney kazığı üzerinde 1,22 katı değerler elde edilmiştir. 


\begin{tabular}{|c|c|c|}
\hline & $\begin{array}{l}\text { BŞEÜ Fen Bilimleri Dergisi } \\
8(2), 531-546,2021\end{array}$ & $\begin{array}{r}\text { BSEU Journal of Science } \\
\text { https://doi.org/10.35193/bseufbd.856498 }\end{array}$ \\
\hline $\begin{array}{l}\text { CIKS SEYH } \\
\text { IVERSI }\end{array}$ & & 2458-7575 (https://dergipark.org.tr/tr/pub/bseufbd) \\
\hline
\end{tabular}

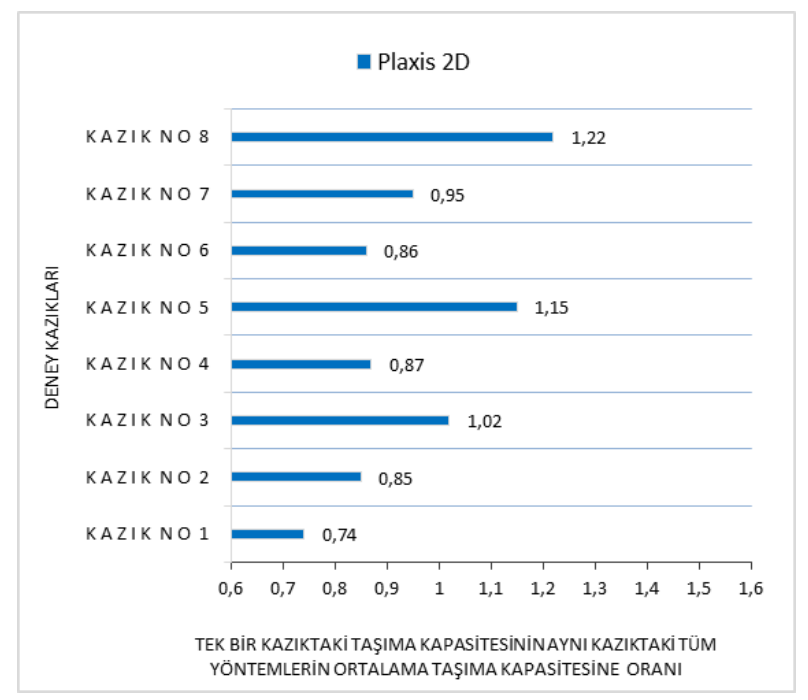

Şekil 9. Sonlu elemanlar yönteminin tek bir kazıktaki taşıma kapasitesinin aynı kazıktaki tüm yöntemlerin ortalama taşıma kapasitesine oranları

Şekil 10'da her bir yöntemin deney kazıklarından elde edilen ortalama değerlerinin tüm yöntemlerin ortalama değerine oranları verilmiştir. Buna göre ortalamaya en yakın değer 0,96 katı ile Bazaara ve Kurkur yöntemi ile elde edilmiştir. Ardından en yakın değerleri veren yöntemler 0,95 katı ile Decourt (1995) ve 0,95 katı ile Plaxis 2D yöntemleridir. En uzak değeri ise ortalama değerin 1,24 katı ile Meyerhof yöntemi vermiştir.

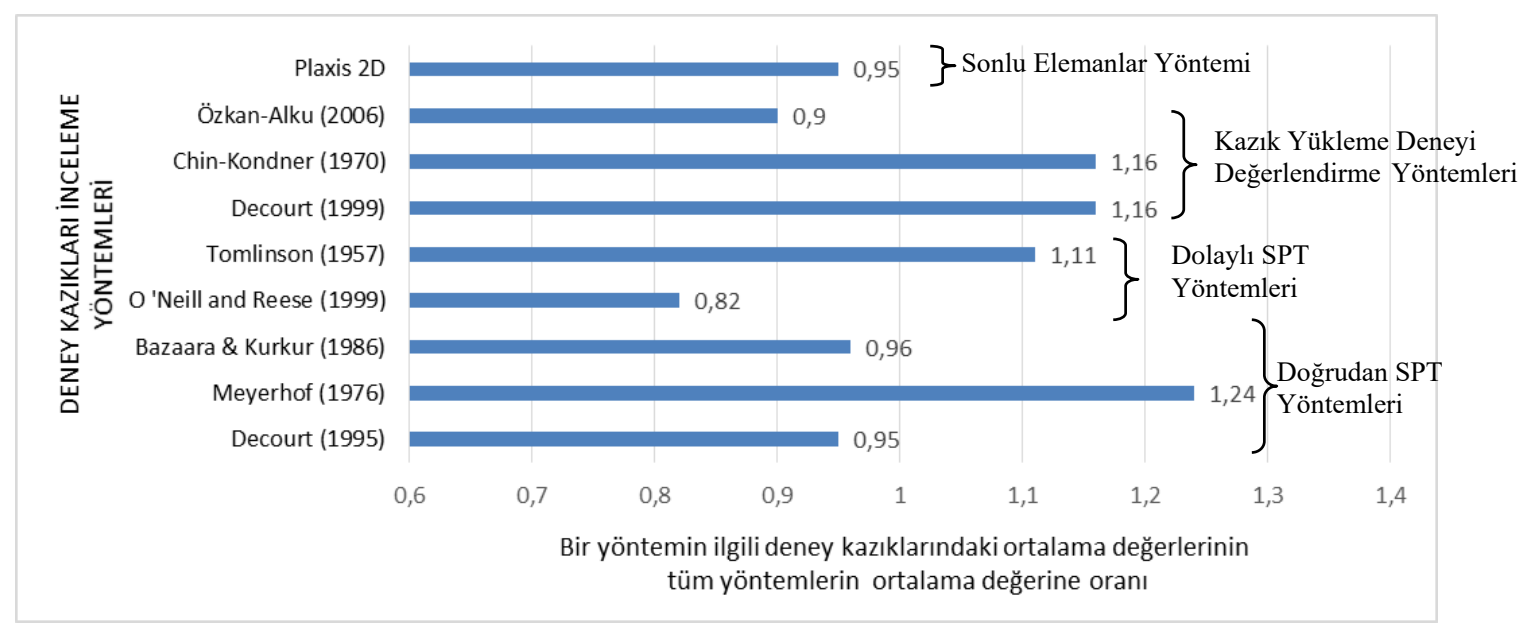

Şekil 10. Deney kazıklarının her bir yöntem için toplam ortalama değerlerinin, tüm yöntemlerin hesap değeri ortalamasına oranları

Deney numaraları 1, 2, 3, 4, 5, 7 ve 8 olan çevresi ayrışmış kaya/sert kil ucu sert kil zeminlerdeki deney kazıklarında SPT verilerinden taşıma gücü veren yöntemler kendi aralarında incelendiğinde Bazaara ve Kurkur yönteminin ortalamanın \%9 daha az göçme yükü değeri verdiği görülmüş̧ür. Decourt (1995) yönteminin Bazaara ve Kurkur yönteminden ortalama \%4 daha fazla göçme yükü değeri verdiği tespit edilmiştir. Çevresi çakıl/kum, ucu sert kil zemin olan 6 no.'lu deney kazığı için ise Decourt (1995) yönteminin ortalamanın \%5 daha az göçme yükü değeri verdiği Meyerhof ve Bazaara ve Kurkur yöntemlerinin Decourt (1995) yöntemine göre yaklaşı \%30 daha fazla göçme yükü verdiği sonucu elde edilmiştir. 1, 2, 3, 4, 5, 7, 8 no.'lu kazıklarda SPT verilerine dolaylı dayalı yöntemler incelendiğinde Tomlinson yöntemi O'Neill and Reese yöntemine göre ortalama değer olarak \%60 daha fazla göçme yükü vermektedir. 1, 2, 3, 4, 5, 7, 8 no.'lu kazıklarda matematiksel modele dayalı kazık yükleme deneyi değerlendirme yöntemlerinden Özkan-Alku yöntemi ortalamanın $\% 10$ daha az göçme yükü değeri vermiştir. Decourt (1999) yöntemi Özkan-Alku yöntemine göre yaklaşık ortalama \%32 fazla göçme yükü değeri vermektedir. Chin-Kondner yöntemi ise Özkan-Alku yöntemine göre \%29 göçme değeri vermektedir. Çevresi çakı1/kum, ucu sert kil zemin olan 6 no.'lu deney kazığı için ise Decourt (1999) yöntemi Özkan-Alku 
yöntemine göre yaklaşı \%4 fazla göçme yükü, Chin-Kondner yöntemi ise Decourt (1999) yönteminin ortalama olarak yaklaşık \%6 göçme değeri verdiği elde edilmiştir.

Çevresi ayrışmış kaya/sert kil ucu sert kil zeminlerdeki 1, 2, 3, 4, 5, 7 ve 8 deney kazıklarında tüm yöntemler birlikte değerlendirildiğinde ise Plaxis 2D ve Decourt (1995) yöntemleri birbirlerine ve ortalamaya en yakın sonuçları vermişlerdir. Aynı kazıklarda Plaxis 2D ve Decourt (1995) yöntemlerinin ortalama değerlerinin yaklaşık \%50 fazlası göçme değeri ile en uzak sonucu veren yöntem Tomlinson 'dur. Plaxis 2D ve Decourt (1995) yöntemlerine göre $\% 17$ daha az göçme yükü değeri ile en az göçme yükünü veren yöntem ise Bazaara \& Kurkur yöntemidir.

Çevresi iri daneli ucu sert kil zemin içerisinde bulunan 6 no.'lu deney kazığı üzerinde gerçekleştirilen göçme yükü analizlerinde ortalamaya ve birbirine en yakın sonucu veren yöntemler ortalamanın $\% 5$ daha az göçme yükü değeri vermeleri ile Decourt (1995) ve Decourt (1999) yöntemleridir. Bazaara ve Kurkur ve Meyerhof yöntemleri ise Decourt (1995) ve Decourt (1999) yöntemlerinden yaklaşı \%32 daha fazla göçme yükü değeri verdiği görülmüştür. Decourt (1995) ve Decourt (1999) yöntemlerinden yaklaşı \%13 daha az göçme yükü değeri ile en az göçme yükü değeri veren yöntem ise Tomlinson yöntemi olmuştur.

\section{SONUÇLAR}

Kazık taşıma gücünün belirlenmesinde tercih edilecek hesap yönteminin güvenli ve ekonomik koşullara uygun seçilmesi muhakkaktır. Aşırı taşıma gücü değeri güvenlik koşulundan uzaklaştıracak, düşük taşıma gücü ise ekonomiklik koşulunu gözardı edecektir. Çalışma ile ortalama değere yakın sonuçlar veren yöntemler ortaya konulmuş olup ortalama değere aşırı uzak sonuçlar veren yöntemler de belirlenmiştir.

- SPT verilerine dayalı Decourt (1995) ile Bazaara ve Kurkur yöntemleri tüm kazıklar içinde değerlendirildiğinde ortalamaya ve birbirine yakın sonucu vermiştir. Meyerhof yöntemi ise Decourt ve Bazaara ve Kurkur yöntemlerine göre yaklaşık \%30 daha fazla göçme yükü vermektedir.

- SPT verilerine dolaylı dayalı O'Neill ve Reese, Tomlinson yöntemleri tüm kazıklar için değerlendirildiğinde Tomlinson yönteminin O’Neill ve Reese yöntemine göre \%35 oranında oldukça uzak daha fazla göçme yükü değeri verdiği sonucuna ulaşılmıştır.

- Kazık yükleme deneyi değerlendirme yöntemleri tüm kazıklar için değerlendirildiğinde Chin Kondner ve Decourt (1999) yöntemlerinin birbirileriyle uyumlu ortalamanın yaklaşık \%16 fazla göçme yükü değeri sonucu verdiği görülmektedir. Özkan-Alku yöntemi ise ortalama değerden \%10 daha az göçme değeri vermektedir.

- Tüm yöntemler ve tüm kazıklar bir arada değerlendirildiğinde ortalama göçme değerlerine en yakın sonuçları Bazaara ve Kurkur, Plaxis 2D ve Decourt (1995) yöntemleri vermiştir. Meyerhof yöntemi Bazaara ve Kurkur yönteminden yaklaşık \%30 daha fazla göçme yükü değeri vererek ortalama en yüksek göçme yükü veren yöntem olmaktadır. O'Neill ve Reese yöntemi ise Bazaara ve Kurkur yönteminin ortalama yaklaşı \%17 daha az göçme yükü değeri vermesiyle ortalama en düşük göçme yükü veren yöntemdir.

\section{KAYNAKLAR}

[1] Kabaca, H. (2018). Kazıkların Taşıma Gücü ve Oturma Parametrelerinin İncelenmesi, Taşıma Gücü İçin Yeni Bir Metot Önerisi, Yüksek Lisans Tezi, Sakarya Üniversitesi, Fen Bilimleri Enstitüsü, Sakarya.

[2] Meyerhof, G. G. (1976). Bearing Capacity and Settlement of Pile Foundations. Journal of Geotech. Eng. Div., ASCE, 102, GT3.

[3] Bazaraa, A. R \& Kurkur, M. M. (1986). N-values used to predict settlements of piles in Egypt. Proceedings of In Situ, 86, 462-474.

[4] Decourt, L. (1995). Prediction of load-settlement relationships for foundations on the basis of the SPT. Ciclo de Conferencias Internationale, Leonardo Zeevaert, UNAM, Mexico, 85-104.

[5] Tomlinson, M. J. (1994). Pile Design and Construction Practise Fourth Edition, E \& FN Spon, an imprint of Chapman \& Hall, 2-6 Boundary Row, London SE1 8HN, United Kingdom, London.

[6] O'Neill, M. W., \& Reese, L. C. (1999). Drilled Shafts: Construction Procedures and Design Methods, Publication No. FHWA-IF-99-025. Federal Highway Administration, Washington, DC. 
[7] Alku, Y. (2006). Kazık Yükleme Deneylerinin Değerlendirilmesi ile İlgili Bir Araştırma, Yüksek Lisans Tezi, İstanbul Teknik Üniversitesi, Fen Bilimleri Enstitüsü, İstanbul.

[8] Mansur, C., \& Kaufman R. (1958). Mansur-Kaufman on Pile Tests. Transactions of the American Society of Civil Engineers, 123(1).

[9] Fuller, F. M., \& Hoy, H. E. (1970). Pile Load Tests Including Quick Load Test Method Conventional Methods and Interpretations. Highway Research Record No.333, 78-89.

[10] Butler, H. D., \& Hoy, H. E. (1977). Users Manual for the Texas Quick Load Method for Foundation Load Testing, FHWA, Office of Development, Washington, D.C., FHWA-IP-77-8, 59.

[11] De Beer, E. E. (1970). Exp. Determination on the shape factors and the bearing capacity factors of sand. Geotec., 2(4), 387.

[12] Chin, F. K. (1970). Estimation of the Ultimate Load of Piles Not Carried to Failure, Proc. 2nd Southeast Asia. Conference on soil Engineering, 81-90.

[13] Brinch-Hansen, P. (1963). Discussion on Hyperbolic Stress-Strain Response, American Society of Civil Engineering, ASCE, Journal for Soil Mechanics and Foundation Engineering, 97, 931-932.

[14] Mazurkiewicz, B. K. (1972). Test Loading of Piles According to Polish Regulations. Preliminary Report No.35, Commision on Pile Research, Royal Swedish Academy of Eng. Science, Stockholm.

[15] Davisson, M. T. (1970). Static Measurement of Pile Behaviour, Proc. Conf. On Design and Installation of Pile Foundations and Cellular Structures, Ed. H. Y., Fang and T.D. Dismuke, Bethlehem, (PA), 159-164.

[16] Osmanoğlu, D. (2007). Tünellerde Zemin Iyileştirilmesi ve Stabilitenin Sonlu Elemanlar Yöntemi Ile Plaxis Programında Analiz Edilmesi, Yüksek Lisans Tezi, İstanbul Teknik Üniversitesi, İstanbul.

[17] Shooshpasha, I., Hasanzadeh, A., \& Taghavi, A. (2013). Prediction of the Axial Bearing Capacity of Piles by SPT-based and Numerical Design Method, Int. J. of GEOMATE, 4(2) 560-564

[18] Aygül, T. (2011). Finite Element Study On Axially Static And Bidirectional Static Osterberg Cell Pile Load Testing, Graduate Thesis, Bogazici University. Science Institute, Istanbul.

[19] Türk Standardları Enstitüsü, Betonarme Yapıların Tasarım ve Yapım Kuralları, TS500/Şubat 2000, ICS 91.080.40, Necatibey Caddesi, 112 Bakanlıklar, Ankara.

[20] ASTM D 1143-81. (1989). Standart Test Method for Piles under Statical Axial Compressive Loads. American Society for Testing and Materials, Philedelphia.

[21] ASTM D 3689. (1989). The Standart Method Of Testing Individual Piles Under Statical Axial Tensile Loads. American Society for Testing and Materials, Philedelphia.

[22] Plaxis 2D 2016. (2016). Reference Manual, Build 8122.

[23] Decourt, L. (1999). Behaviour of Foundations under Working Load Conditions. Proc. of the 11th PanAmerican Conf. on Soil Mechanics and Geotechnical Engineering, Dolguassu, Brasil, 4, 453-488. 